\title{
THE STAR AND THE REVOLUTION \\ ŽIŽEK, KAFKA, AND THE ALCHEMY OF SUBTRACTION
}

Cory Stockwell

Two possibilities: making oneself infinitely small or being so. The second is perfection, that is to say, inactivity, the first is beginning, that is to say, action.

-Kafka, The Blue Octavo Notebooks

0

September 6, 2013, Slavoj Žižek published an op-ed in The Guardian titled "Syria Is a Pseudo-struggle." In the article, which deals with the by then two-year-old conflict in Syria, Žižek adduces the reasons for which this conflict, as per his title, is not a real struggle but rather a kind of proxy war that cannot but turn out badly. In Syria, he writes, "there are no clear political stakes, no signs of a broad emancipatory-democratic coalition, just a complex network of religious and ethnic alliances overdetermined by the influence of superpowers"; what is missing is the "strong radical-emancipatory opposition whose elements were clearly perceptible in Egypt." For these reasons, Žižek argues against any military intervention on the part of Western powers (at the time he was writing, some form of Americanand French-led intervention seemed highly likely), which, in his view, would end up doing more harm than good.

In a sense, the article is unremarkable: it doesn't break any new theoretical ground or offer startling new insights into the conflict; Žižek's primary aim, it seems to me, is to take a position, to add his voice to the chorus of those coming out against "Western" involvement. I begin with this op-ed, however, because it touches upon a larger issue in Žižek's work (and, more broadly, in contemporary politics), an issue that will be my main concern here: that of revolution. The conflict in Syria, after all, is often referred to as the "Syrian Revolution," and many of those who have named it thus wish to position it 
within the series of upheavals that has come to be known as the Arab Spring, of which Syria (I will use to the name to refer to the phenomenon, as Žižek does) would be the latest and bloodiest example. For Žižek this is clearly not the case, and I take his judgment seriously, for the simple fact that he has thought long and hard about the question of revolution. For all the diverse subjects he tackles, one thing that never changes in his work is his aim to think in the service of a radical politics, a politics that it would be no exaggeration to call one of revolution.

Why, then, is Syria not a revolution? The answer is already contained in the title of the article: while Syria may look like a revolution (complete with a "bad dictator," as Žižek puts it, and an oppressed population), this is only an appearance, a semblance; the underlying reality is different. The title's use of the combining form "pseudo-" is perfect, for this is the register in which Žižek speaks for the entire article: he writes that the struggle in Syria "is ultimately a false one"; that it displays in a "condensed form ... all that [is] false in the idea and practice of humanitarian interventions"; that the moral outrage at the possible use of poisonous gas "is fake"; that "this pseudo-struggle thrives" only because a true opposition, like the one that was found in Egypt, is absent. The distinction that structures the entire article is that of truth (Egypt) and falsehood (Syria); in a sense, it is the most classical "ideological" argument, not only because to call the Syrian pseudo-struggle a revolution is to engage in obfuscation but also because the entire problem with Syria, for Žižek, is that it lacks the material basis that would make it a true revolution. What remains of the secular opposition in Syria, Žižek seems to suggest, is stuck in the trap of insisting on Western clichés such as freedom from oppression-it is a negative struggle, in other words; what is missing is "the radicalization of the struggle for freedom and democracy into a struggle for social and economic justice"-what is missing, in other words, are the material bases of revolution. ${ }^{1}$

The article thus fits seamlessly into Žižek's theoretical framework, which is nothing if not resolutely materialist. In at times very different ways, he insists on a materialist perspective throughout his work and hence quite logically aims some of his harshest criticism at those he deems idealists: as soon as one approaches the terrain of idealism, he seems to suggest, there is the danger of obscurantism. This is why 
he writes that in Syria, "the wind blows ... towards Afghanistan": while in Egypt, even before the revolution, a radical opposition was already present, already beginning to "articulate its interests outside the scope of state and religious institutions," this was not the case in Syria. The distinction is quite simply that of idealism (Syria) versus materialism (Egypt); in Egypt, the revolution was in some sense already under way even before it began, in the sense that material revolutionary forces were already at work, while in Syria, there is a gap of sorts between the idealism of the secular opposition and the real material labor they would need to undertake in order to truly call themselves revolutionaries.

Žižek makes very similar claims in what are perhaps his most overtly "revolutionary" texts, a series of introductory essays to collections of writings by some of history's most famous revolutionaries: Robespierre, Lenin, Trotsky, and Mao. ${ }^{2}$ In the Lenin essay, for example, titled "Between the Two Revolutions," Žižek writes of a gap between the "two revolutions" of 1917 on which, he claims, Lenin insisted.

This gap is the gap between revolution qua the imaginary explosion of freedom in sublime enthusiasm, the magic moment of universal solidarity when "everything seems possible," and the hard work of social reconstruction which is to be performed.... This gap-a repetition of the gap between 1789 and 1793 in the French Revolution-is the very space of Lenin's unique intervention: the fundamental lesson of revolutionary materialism is that revolution must strike twice, and for essential reasons. The gap is not simply the gap between form and content: what the "first revolution" misses is not the content, but the form itself-it remains stuck in the old form, thinking that freedom and justice can be accomplished if we simply put the existing state apparatus and its democratic mechanisms to use.... Those who oscillate, those who are afraid to take the second step of overcoming this form itself, are those who (to repeat Robespierre) want a "revolution without revolution." (7-8, Žižek's emphases) ${ }^{3}$

The limitation of the first step, in other words, is that it continues to speak the language of the ancien régime; it aims at something new but remains caught in the logic (e.g., institutions, laws) of the order that it is seeking to replace, and this necessitates the second step, in which the revolution, in and through the creation of a new order, begins to speak its own language, to act according to its own logic - to create not only new content but, to use Žižek's language, a new form. From this standpoint, it is clear that Syria is stuck in the "first step," that of 
simply gaining power. This first step is of course necessary, but the lesson of the Lenin essay is more complex than this: what is more complex is precisely the gap in question. At one point in the essay, Žižek notes that Leninism arose out of a moment of catastrophe or (borrowing this term from Badiou) disaster of the left, a moment at which the left had completely lost its bearings. On the one hand, Lenin's lesson is that it is precisely at such a disastrous moment that the time is ripe for revolution, ${ }^{4}$ and yet this statement is misleading, since in fact, the time is always ripe: the time for revolution is always now.

In 1917, instead of waiting until the time was ripe, Lenin organized a preemptive strike; in 1920, as the leader of the party of the working class with no working class (most of it being decimated in the civil war), he went on organizing a state, fully accepting the paradox of the party which has to organize- even recreate-its own base, its working class. (6)

The time is always ripe for revolution because of the latter's nature: revolution is that which creates its own conditions, its own people, its own subjects. Its own constellation, one might say, as Žižek does toward the end of the essay, when he writes that Lenin's "fundamental experience was that of being thrown into a catastrophic new constellation in which the old co-ordinates proved useless, and who was thus compelled to reinvent Marxism" (11); the lesson for those who seek "to retrieve the same impulse in today's constellation" (ibid.) is that the time of the revolutionary gap is paradoxically always right now. This is reminiscent of an argument Žižek makes about John Brown, whom he calls "the key political figure in the history of the USA" $(2006,363)$ because of his revolutionary practice: contrary to the "gradualists" who, while they were opposed to slavery, imagined true equality only in a distant future (blacks "weren't ready" to be fully functioning citizens in a democracy), for John Brown (here Žižek quotes Margaret Washington) "'practicing egalitarianism was a first step toward ending slavery.... He made it clear that he saw no difference [between blacks and whites], and he didn't make this clear by saying it, he made it clear by what he did.'"5 Žižek calls this the politics of prescription, and it is very close to the concept of the performative, whereby an act (linguistic or otherwise), rather than referencing an already existing entity, brings this entity into being (just as, for Lenin, the party had to bring about the very working class it sought to represent). ${ }^{6}$ 
There is, in other words, a gap that revolution must fill. One could easily counter at this point and say: how can this gap, this empty space, not be idealist? Yet this is precisely the distinction between Syria and the other revolutions Žižek discusses. The gap is indeed idealist in Syria, in the sense that revolution is absent, constitutes a "beyond," because there is currently no material evidence of radical politics. But this is not the case for, say, Lenin or John Brown: what is interesting about them is that they are already living in postrevolutionary states prior to the revolutions in question; the gap between a now and a revolutionary future is a gap of the present moment itself, for the coming revolution is in a sense already here. The gap in question is therefore material: Lenin and John Brown already exist in the very time and space that is to come; the gap lies between the present and itself.

In order to examine further the notion of the gap in Žižek, I turn now to one of his longest texts, The Parallax View (2006), which is entirely devoted to the examination of a certain gap. A word of caution is in order here, for Žižek never suggests that what he describes as the parallax gap is the same as the "revolutionary gap" I have been examining. But The Parallax View makes clear that the gaps in question are exceedingly close, if not identical. Žižek begins the book's Introduction, "Dialectical Materialism at the Gates," with a discussion of a pair of news stories from 2003. One of them concerns the development of "psychotechnic' torture" (3) in Barcelona during the Spanish Civil War, not by Franco but by the revolutionary forces opposing him: inspired by surrealism, a French anarchist developed jail cells with beds placed at angles that made them impossible to sleep on, walls that were curved and covered with spirals, for example, all designed to drive prisoners mad. The second concerns the discovery that Walter Benjamin did not take his own life, as had always been supposed, but was killed by Stalin's agents, so as to prevent the development of the "Theses on the Philosophy of History" into a book. What the stories share, Žižek explains,

is that the link they establish is an impossible short circuit of levels which, for structural reasons, can never meet: it is simply not possible, say, for what "Stalin" stands for to move at the same level as "Benjamin," that is, to grasp the true dimensions of Benjamin's "Theses" from a Stalinist perspective. The illusion on which these two stories rely, that of putting two incompatible phenomena on the same level, is strictly analogous to 
what Kant called "transcendental illusion," the illusion of being able to use the same language for phenomena which are mutually untranslatable and can be grasped only in a kind of parallax view, constantly shifting perspective between two points between which no synthesis or meditation is possible. (3-4)

Parallax thus denotes an impossible conjunction between phenomena that can never quite meet, yet still somehow occupy the same space, as if they were, to employ an image Žižek uses not only in this discussion but often in his work, "on the opposed sides of a Moebius strip" (4) - a kind of relation of the unrelatable. What is at stake is "an insurmountable parallax gap, the confrontation of two closely linked perspectives between which no neutral common ground is possible" (ibid.): this gap, which holds together the phenomena on either side of it, is nonetheless not a space of mediation but is rather insurmountable, in that there is no possible passage from one side to the other.

Wouldn't the notion of a gap, however, tend toward idealism, an "emptiness" lying between solid entities? This is not the case for Žižek, for whom the gap in question is a decidedly material element of a unity, that aspect of an entity by which it at once affirms itself and its difference from itself-by which, to paraphrase Lacan, it works because it doesn't work. Far from a struggle between two sides of an opposition that can never come together, the parallax gap designates "the inherent 'tension,' gap, noncoincidence, of the One itself" (7). Parallax is the unity of that which can never be unified: it is at once the whole and that which defers wholeness, a unity at odds with itself. Rather than an empty space, therefore, it is a kind of object, in the most literal sense of the term- "that which objects, that which disturbs the smooth running of things" (17). As he explains in one of the book's most beautiful passages, parallax, far from "a mere difference between objects," is "the pure difference [that] is itself an object" (18).

All of this is intimately related to Žižek's thought about radical politics and the specific tradition out of which this thought arises. While the parallax gap, he writes, appears to enact a "Kantian revenge over Hegel" (4), in that, because it can never be mediated or sublated, it seems to undermine the possibility of dialectics, in fact this is not the case: "far from posing an irreducible obstacle to dialectics, the notion of the parallax gap provides the key which enables us to discern its subversive core" (ibid.); indeed, the theorization of the parallax gap is 
the "first step in the rehabilitation of the philosophy of dialectical materialism" (ibid.). It is therefore unsurprising that the figure of the gap comes up in some of Žižek's most overtly "revolutionary" writings. If dialectical materialism is the thought that permits access to parallax, to enter into the space of its difference, then the revolutionary is the one who finds a way to work within this gap. Parallax constitutes nothing less than the space of revolution, a gap that is impossible to traverse but that revolution somehow, impossibly, traverses all the time, not by bridging it but rather by existing within it, putting its "pure difference" into play.

The figure of the gap, then, far from bringing Žižek outside a materialist framework, seems to locate him most solidly within it. I would therefore like to ask him a distinctly materialist question: why does he refuse to talk about the stars?

Stars, after all, are everywhere in this book, despite the fact that Žižek never deals with them. First, there is the book's and, more broadly, Žižek's focus on revolution. As is well known, this term comes from astronomy or, more broadly, the study of the stars. I am not suggesting that everyone who talks about revolution must deal with stars, especially as the term has migrated to such a great extent since its incorporation by political thought. However, this is not the only "starry" reference in Žižek's book: the second, and most obvious, comes from the title of the book itself. While the term "parallax" is not restricted to astronomy, it is most often associated with the latter, as its bestknown use is as a tool to measure the distance to stars. This is not lost on Žižek, who names the three main sections of the book "The Stellar Parallax," "The Solar Parallax," and "The Lunar Parallax." Yet he never explains these titles, never discusses his reasons for employing a language of stars to organize his book. There may be good reasons for this: perhaps he is suggesting, in the spirit of parallax, that in order to approach the stars, one must do so indirectly; in this case, Žižek, rather than simply speaking about parallax, would be allowing the latter to intrude upon the very form of his text, positing the stars as an inaccessible yet inherent component of the book's structure.

There is one place, however, at which Žižek enters into a direct and overt examination of a star, all the while neglecting to mention that it is a star: I am speaking of his discussion, at the very end of the book's first section, of Kafka's Odradek. ${ }^{7}$ The reference is of course to 
the story "The Cares of a Family Man" ("Die Sorge des Hausvaters"), the "object" of which is Odradek, the tiny figure who occupies, without exactly living in, the home of the family man of the story's title. Žižek brings in Odradek in order to disturb what he views as the "all too human" Levinasian understanding of alterity, in which the other is conceived of as an abyss from which ethical responsibility emanates: for Žižek, this conception obfuscates what psychoanalysis (and other traditions) have sought to think under the heading of the neighbor, a monstrous alterity that is part of me but nonetheless exceeds my humanity (that is in me more than me, to paraphrase Lacan), a "creaturething" that perturbs the wholeness of my universe. Odradek is for Žižek just such an object. His discussion of Odradek begins in a subsection entitled "Odradek as a Political Category," and shortly after transcribing the entire story (which takes up less than a page of the book), he has this to say about it:

Odradek is simply what Lacan, in Seminar XI and in his seminal écrit "Positions de l'inconscient," developed as the lamella, the libido as an organ, the inhuman-human "undead" organ without a body, the mythical presubjective "undead" life-substance, or, rather, the remainder of the Life-Substance which has escaped the symbolic colonization, the horrible palpitation of the "acephalic" drive which persists beyond ordinary death, outside the scope of paternal authority, nomadic, with no fixed abode. (117-18)

It is clear, then, that Žižek will read Odradek within a Lacanian framework: elsewhere he states that Odradek is "jouissance embodied" (115), and that it is "the father's sinthome, the 'knot' onto which the father's jouissance is stuck" (121). Odradek, in other words, is a kind of excess, an object that "gets in the way," and Žižek suggests at the end of this subsection that the properly revolutionary task is to avoid sublimating this inhuman excess (by subsuming it within already existing frameworks, thereby domesticating it), and confront it head on.

Curiously, however, Žižek's setting out of this theoretical framework goes against something he says at the beginning of his discussion of Odradek, where he writes that reading Kafka requires a work of "unlearning ... so that we become able to open up to the raw force of Kafka's writing ... a kind of childish naivety has to be regained in order for a reader to be able to feel the raw force of Kafka's universe" (114). He then lists the three "interpretive frames" that hinder 
the ability to access this naivety: the theological, the sociopolitical, and the psychoanalytic. On this point, I am in full agreement with Žižek, but doesn't this make it all the stranger that, immediately after transcribing the story, he subsumes Odradek within a Lacanian framework? Doesn't this threaten to position Odradek within one of the "interpretive frames" (the psychoanalytic) that supposedly take away from the ability to read naively; doesn't it go against the claim that "objects" such as Odradek undermine conceptual universes? More broadly, doesn't this non-reading of Kafka (for, strangely, Žižek never really undertakes a close reading of Kafka's text, despite ostensibly devoting several pages to it) threaten the very materialism within which Žižek seeks to place his own work-wouldn't a truly "materialist" reading of the text have to undertake a close examination of the material of which it is composed, look as closely as possible at the very words that make it up?

In order to examine the material being of Odradek, therefore, I turn to another text, one that represents the closest reading of "The Cares of a Family Man" that I am aware of, namely Werner Hamacher's essay “The Gesture in the Name." I turn to Kafka's story and Hamacher's reading of it not to move on from Žižek but rather to take up his imperative of reading Kafka naively, so as to locate within the story the very materialist potential of parallax of which Žižek speaks.

One of the strangest things about "The Cares of a Family Man" is that, while most of it deals with the family man's or "housefather"'s (to translate the title more literally) reflections on Odradek's "being" its appearance, its movements, its utterances-it begins with an etymological discussion of the creature's name. Here is the first of the story's five paragraphs:

\footnotetext{
Some say the word Odradek comes from the Slavic, and on this basis they seek to ascertain the formation of the word. Others again say it comes from the German and is only influenced by the Slavic. The uncertainty of both these interpretations, however, allows one to conclude with justice that neither hits the mark, especially since one cannot find a meaning of the word with either of them. (Qtd. in Hamacher, 319)
}

As Hamacher notes, this opening paragraph puts the family man in "the position of a hermeneut," examining the word for "certainty and meaning" (319); he then undertakes a similar sort of work, meticulously 
examining the way the name Odradek contains or echoes an entire series of terms in both German and Czech. However, rather than arguing, in the spirit of such critics as Max Brod and Wilhelm Emrich, that the confluence of words in Odradek produces a definitive meaningthat Odradek must mean this or that-Hamacher takes the opposite approach. He writes:

Any interpretation of "Odradek" that lays claim to certainty, conclusiveness, and meaning-and these are the hermeneutic principles of both "the family man" and the etymologists he criticizes-must miss "Odradek" because "Odradek" means dissidence, dissense, and a defection from the order of meaning. "Odradek" thus "means" that it does not mean. His discourse says that he denies this discourse, that he runs off course, that he de-courses; his name says that he has no name. (320-21)

Hamacher, in other words, does not deny that an entire multilingual series of terms (rada, rád, Rede, radix, and so on) coalesces in Odradek, but he argues that the combination or multiplicity of these terms works not so much to produce as to lessen meaning, to bring meaning away from itself, resulting not in more certainty but less. "Odradek," he writes, "is the leap from the series of rationality's normative positionings; he is nothing but ex-position" (322).

Though he speaks a very different theoretical language, Hamacher here seems quite close to Žižek in his insistence on Odradek's disruption of meaning. It becomes clear how this suspension of meaning works, however, only after one turns away from Odradek's name and toward its being (though the question is precisely whether this is possible). In the story, this occurs in the passage from the first to the second paragraph. At first, this passage can seem to constitute an abrupt shift, but as Hamacher shows, this is not the case. Here is the family man's detailed description of Odradek from the second paragraph:

At first glance it looks like a flat star-shaped spool for thread, and indeed it does seem to have thread wound upon it; to be sure, they are only old, broken-off bits of thread, knotted and tangled together, of the most varied sorts and colors. But it is not only a spool, for a small wooden crossbar sticks out in the middle of the star, and another small rod is joined to that at a right angle. By means of this latter rod on one side and one of the points of the star on the other, the whole thing can stand upright as if on two legs. (Kafka 1992a, 428) 
The narrative thus passes from the word to that which the word designates, from name to object, signifier to signified. But as I have already mentioned, for Hamacher this is not a "passage" at all. Here is his reading of this paragraph:

What first appears as a realistic description of a home-made homunculus can also be read as a description of a word-object, a rebus generated from the individual pieces of the word "Odradek" and the "translated" name Kafka. The words for "spool" and "bobbin" in Czech are cívka or cevka, which are similar enough orthographically and phonetically to the name Kafka to function as its paronyms. And "star" in combination with rade-Rabe from "Odradek" can be read as an allusion to the star Algorab in the constellation of the Raven and also to the hexagram, the signet-star that was used for the first time in Prague as the Magen David, the "official" sign of the Jewish community. This hexagram then lets one read in Kafka's name all the letters organized in a ring around an empty middle: the letters K A K A. And the middle letter F appears in Odradek's figure as a "small crossbar" that "sticks out of the middle of the star." (323-24)

By combining the hexagram with the crossbar, in other words, one obtains "the name 'Kafka' distorted into a thing" (324): the letters of Kafka's name literally constitute this image. "Odradek" is thus not simply a name that refers to a thing: it is (to use Hamacher's terms) a "name-thing," a "word-object," whose very being expresses Kafka's name and in whom, therefore, the distinction between name and thing disappears.

The originality of Hamacher's work here lies in the fact that virtually all of the work on the relationship between language and being in recent critical theory maintains the separation between the two, maintains the "and," even the most "monistic" work, such of that of Deleuze, who, after Spinoza, speaks, in various ways, of language and being as different modes that nonetheless express a common unity. What Hamacher is saying is even more radical: not only are language and being intimately related; they are in a sense one and the same, which is very close here to a Kabbalistic understanding of language, in which the letters that are language's raw material possess a material existence and act as the building blocks of things. ${ }^{9}$ One could even think of this as a more radical materialism than that of Žižek, given that Hamacher thinks outside the notion of the gap: there is no gap between word and object, one doesn't pass any border to move from 
one to the other, one doesn't even go from the "outside" to the "inside" of a Moebius strip; the word constitutes being itself. But Hamacher does not simply argue that the letters of Kafka's name make up Odradek's being. More precisely, Odradek ruins or impoverishes Kafka's name from within: Odradek, after all, is both broken down and finished, a ruin that is nonetheless complete. I follow Hamacher's reasoning here, but this impoverishment is at the same time the reason for which there is something amiss in his understanding of the "word-object" of Kafka's story.

Among the many details that the housefather provides in his description of Odradek-a spool, ${ }^{10}$ some threads, a crossbar-I want to focus on one that to my mind is key, in that it constitutes the entire shape or form of the creature and thus serves as a basis for all of its other characteristics and properties: ${ }^{11}$ Odradek, as the housefather notes three times in his description, is a star. This, of course, is the trait on which Hamacher also spends most of his time, in arguing that the letters of Kafka's name (other than the F) compose a specific star, the Magen David. ${ }^{12}$ There are several reasons, in my view, to object to this understanding of the star, and they have to do with what Hamacher himself refers to as Odradek's "nomadic" existence. ${ }^{13}$ The word is well chosen, given that Odradek famously has "no fixed address" (or, depending on the translation, an "undetermined address"), ${ }^{14}$ that he moves back and forth incessantly, that he cannot be got hold of: wherever you look, he is already somewhere else; even his name speaks this nomadism, given that, as I have noted, Hamacher claims that Odradek "'means' that it does not mean." Far from a mere trait, nomadism is clearly its very being. But doesn't this render any attempt to fix this being in a specific name (Kafka) or a specific symbol (the Magen David) problematic? To do so, it seems to me, is at best to seek to anchor Odradek's nomadism in a particular form; at worst, by making this claim, Hamacher brings himself uncomfortably close to those critics who read Kafka "symbolically," arguing, for instance, that Joseph K. "really is" Kafka.

If any community can be said to have an "undetermined address" and to constitute a nomadic presence, it is of course the Jews, especially in the specific context in which Kafka is writing. Still, is there not something intrusive about Hamacher's conflation of Odradek with an official sign (especially since, as Gershom Scholem notes, even this 
status of "official sign" is highly questionable), ${ }^{15}$ and, indeed, with any particular community, regardless of how nomadic this community may be? I am not claiming that there cannot be resonances between Odradek and particular communities, symbols, or contexts, but to go so far as to identify the creature with this symbol seems out of place when one considers Odradek's nature; if Odradek is in some way pure movement, must this not also be true of its shape?

My second reservation with Hamacher's reading is as follows. If Odradek is a word-object, then it should fit unobtrusively within both the world of words and the world of objects: among its nomadic qualities should surely be an ability to move effortlessly between these worlds. But this is precisely what Hamacher's hypothesis would not allow. To understand this, it suffices to look as "naively" as possible at the text of Hamacher's essay-to simply glance at the page and see what attracts attention. Immediately after writing that the letters of Kafka's name are "organized in a ring around an empty middle: the letters K A K A" (324), Hamacher inserts a footnote, in which he explains further the appearance of this word-object. However, the note begins not with text but with the image of the Star of David: looking at the bottom of the page, one sees the number (31) of the footnote, followed immediately by a hexagram. In Hamacher's understanding, of course, this is not exactly an image, or at least it lies on the border between text and image, insofar as it is composed of letters. Yet the effect on the naïve reader is clear: this shape stands out, stands apart from everything else on the page, in that it can't be read (to do so, one must make the effort of deciphering it, reading "into" it): it has no typographical function and thus falls outside the very concept-wordobject, name-thing - it is meant to illustrate. Strangely, standing out is precisely what Odradek does not do; one can imagine seeing such a figure and recoiling in fear or amazement, yet the family man's narration is utterly calm, which, if one thinks about it, fits perfectly with the title of the story: the translation of Sorge by "Cares" is fine, in my view, but it should be kept in mind that the German term also connotes "worries" or even "anxiety," the expression of which is often perfect calmness: Heidegger famously says of anxiety that "a peculiar calm pervades it" (88); Blanchot writes: "Were you in anguish [angoissé], you wouldn't be" $(1995,11)$. Odradek, unlike the Magen David on Hamacher's page, fits in seamlessly to its surroundings. ${ }^{16}$ 
Finally, I want to consider Odradek's movement from the same naïve perspective. It is no exaggeration to say that Odradek is always moving. It is true that it occasionally stands still, but consider its undetermined address and the fact one cannot find a logic to its movement: it is not on its way anywhere but simply on its way; rather than ceaselessly going back and forth between points, it occasionally stands still, and this too constitutes a mode of its movement. Hamacher's labeling of it as "nomadic" calls to mind a point made by the most prominent thinker of nomadism in recent philosophy, Deleuze: to be a nomad does not mean to be in constant movement (in fact, the nomad is often the one who is most still) ${ }^{17}$; rather, it designates a certain relation to space, whereby movement, far from an occasional interruption of stasis, is itself constitutive of being. How, then, does Odradek move about? The housefather uses only one verb throughout the entire story to describe this movement, when at the end he wonders whether Odradek "will always be rolling down the stairs" (1992a, 429) before the feet of his children and his children's children. The German verb translated as "rolling down" is hinunterkollern, which upon removal of the prefix becomes kollern, an archaic variation of the modern kullern, which means "to tumble" or "to roll." ${ }^{18}$ But this presents a difficulty, for how it is possible for this star to roll or tumble about-isn't it difficult to imagine a hexagram (or a pentagram, for that matter) rolling, especially as deftly as the "extraordinarily nimble" Odradek is supposed to?

The limit of Hamacher's reading of the story, in other words, is not that it does not go far enough but rather that it goes too far: by construing Odradek as a Star of David, it moves beyond the materiality that it begins by positing. To understand Odradek's form requires an insistence on naivety, that of remaining as close as possible to what Kafka says about it. Odradek, he writes, is a star that rolls about. Look one place and it is already another: its very being is movement. It gives forth a kind of anxiety, all the while (indeed in this very act) bringing about nothing new, simply remaining the same. It is at once outside and inside, going away while coming back, and vice versa. These are the qualities of this little star-in German, Sternchen. Which also means asterisk.

Asterisk, from the Greek asteriskos, a diminutive of astēr, or star. Wouldn't an asterisk, with its rays-most commonly six, but at times 
eight — that resemble the spokes of a wheel, be quite adept at rolling? Indeed the grammatical function of the asterisk is akin to a rolling, in that its function is to move (the gaze of the reader, the text itself) elsewhere: the $O E D$ notes that it often refers to "a note at the foot or margin of the page"; it can indicate "the omission of words and letters"; it denotes something that sticks out, that doesn't quite belong, such as a colloquialism, poor grammar, vulgarity; in linguistics, it stands for, among other things, the hypothesis of an origin that cannot be proven. ${ }^{19}$ The asterisk, in other words, is a nomad of sorts, always moving toward an outside, an otherness, ${ }^{20}$ but it doesn't do so by leaving the text, by leaving text: it is one typographical sign among many, ${ }^{21}$ indeed more banal than others in that it doesn't say anything in and of itself (it is not pronounced), and merely points toward something the author didn't deem worthy of inclusion in the text "itself." 22 To make an asterisk is the most commonplace of gestures: one need only strike a key (while holding down another) or draw a few lines; it is at once completely ordinary (fitting seamlessly within the text) and strange: in pointing toward trains of thought or avenues of exploration that didn't quite make it into the body of the text, it gives the latter an air of arbitrariness, suggesting that things didn't have to be this way.

Its movement, then, is in a sense the reverse of Hamacher's hexagram (both the one he conceives Odradek as forming and the one he actually includes in a footnote of his text), in that, while it may seem to add something to the text-itself, the notes to which it refers-it in fact takes something away: what it removes from the text is a totality, a finality, a sense of wholeness; the words that it adds in the margin act as a subtraction from rather than an addition to the text. In the arbitrariness that it introduces, it somehow makes the text less than itself-ruining it, all the while leaving it intact, to echo Blanchot, ${ }^{23}$ or, to paraphrase Kafka, introducing a meaninglessness into the text without endangering its finality or wholeness. ${ }^{24}$ What this little star introduces into the text is a work of impoverishment.

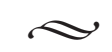

Thinking in terms of impoverishment gives rise to another naïve question, one occasioned by the fact that Odradek is a star: why is it below rather than above, on the ground rather than in the sky? The 
nature of stars as celestial objects, the fact that they occupy distant realms, may shed further light on why Žižek neglects to discuss them, for don't they often constitute an idealist rather than a materialist motif? Possibly the most famous mention of the stars in the history of philosophy, from Kant's second Critique, reflects this understanding: "Two things fill the mind with ever new and increasing admiration and awe [Bewunderung und Ehrfurcht], the more often and more steadily one reflects on them: the starry heavens above me and the moral law within me" (5:161, translation modified). For Kant, in other words, the stars are the object of awe, an "idealist" awe in that the stars (like the moral law) constitute a realm of perfection that can never be attained; it is thus unsurprising that Žižek spends several pages in The Parallax View criticizing this framework, that of the Sollen or symbolic ideal, which he describes as "what you are striving for but can never accomplish" (92). ${ }^{25}$ What is interesting for the purposes of this essay is that Kant, speaking well after the Copernican revolution, reflects an ancient understanding of the stars. Ancient Greek astronomy is representative in this respect, opposing an earthly "sublunary" realm in which "everything was subject to change; nothing was eternal" to a "superlunary region" in which "everything was composed of the fifth element called 'quintessence.' Here, all motion was based on the ideal movement of a circle, which was changeless and eternal" (van Gent 6). As with the ancients, Kant posits the stars as a realm of perfection, and conceives of the task of humans as that of emulating this perfection, all the while knowing that actually attaining it is impossible.

By bringing his star down to earth (indeed, right down to the housefather's feet), by rendering it tiny rather than enormous, Kafka therefore goes against an entire tradition: far from Kant's object of awe, Kafka's star is mundane, everyday, the lowest rather than the highest. Yet this is not exactly correct, for, as Kafka states repeatedly, this is still a star, no less so for having been brought down to Earth. How, then, should one conceive of this back-and-forth movement between the mundane and the awesome? Perhaps the best word to describe it, given Odradek's starry nature and the fact that the family man refers to its return to the house after periods of absence as unweigerlich or inevitable, would be "revolution." Yet this relationship between high and low is not exactly that of a back-and-forth movement: in 
Odradek, awe and mundaneness are somehow one; each expresses itself through the other. The revolutionary movement in question (the term works particularly well since what is at stake is a star) is one of parallax: Odradek, to quote Žižek, is not looking for "any kind of middle ground," and its aim is not that of "avoiding the two extremes" (that of high and low); what it does, on the contrary, is "assert the truth of both extremes" $(2006,258)$.

Indeed, it does so all at once, in a single stroke. And it is for this reason that, all the while that it embodies a kind of parallax, it at once undermines the concept of parallax, at least in the way it is conceived of by Žižek. I will think about this by reflecting on an aspect of Odradek on which I have not yet focused, despite the fact that it has been implicit throughout: the housefather describes it as flat. "Eine flache sternartige Zwirnspule," he states, suggesting an intimate connection between its flatness and its starry nature, all in a language that is just the slightest bit different from that of Žižek, in that its terminology is not that of a "middle ground" or "two extremes." Between Odradek's starry and earthly natures, between its mundaneness and its awe, there is no space at all, not even a gap: each immediately expresses or articulates the other. ${ }^{26}$ (Even Žižek's beautiful formulation of the "pure difference that is itself an object" slightly misses this, for it leaves intact the framework of the gap, of the slight difference between viewpoints.) It may seem that there is indeed a back-and-forth movement here, for while the star's mundaneness constantly lessens its awe, doesn't its awe constantly render it something more than mundane? But this is not exactly the case, as a fuller examination of its flatness makes clear. I have spent a great deal of time in this essay thinking about Odradek's appearance and indeed, most readings of the story have done the same. But in a sense, this goes against the spirit of the story: isn't one of its most important aspects the fact that the housefather never tells us exactly what Odradek looks like, giving only a series of clues, of more or less precise indications? It may be that to imagine Odradek as any specific form or shape is to do the story a disservice. Yet it is not as though the housefather said nothing about this; on the contrary, his description is very precise, if in an inexact way: it is not so much that he declines to describe Odradek as that this description constantly withdraws, slipping through the reader's fingers the moment he or she believes to have taken hold of it. 
This withdrawal-whereby Odradek's flatness becomes something less than it already is, whereby a movement of subtraction takes place without redemption by a concomitant increase-comes to form the language and, indeed, the tone of the story. It is on display, for instance, in the narrative's play of pronouns. At the beginning of the story, the father constantly refers to Odradek as "it," while in the final paragraphs this "it" is replaced by "he." On the one hand, there is a simple grammatical explanation for this: the es of the early paragraphs takes the place of the terms Wesen (being, creature) and Gebilde (entity, figure, shape) by which the housefather refers to Odradek, while the er of the later paragraphs stands in for the proper noun "Odradek." But this is precisely the point: every attempt to make Odradek a subject, to anthropomorphize it, is haunted by its "creature-ness," its "shape-ness," the fact that it is a simple being; when the "he" of the later paragraphs replaces the "it" of the earlier ones, in other words, the "it" does not simply disappear but rather remains within the "he," constantly lessening it, hollowing it out from within (one thinks here of Odradek's lungless laughter). This lessening is also evident in the etymological discussion with which the story begins: three times in the first paragraph, the housefather refers to "Odradek" not as a name but as a word ("das Wort Odradek," per the story's first sentence). The work that this word undertakes on the name echoes that which the "it" undertakes on the "he": that of an impoverishment, a lessening, a movement away from a fullness; the word hollows out the name, makes it something less than what it is.

It would seem, then, that to ascribe to Odradek the form of an asterisk would be to betray this work of impoverishment: wouldn't this figure or shape be something over and above the story itself, adding something to it and hence going against the work it is doing? But the asterisk is the perfect expression of this impoverishment, given that its function is to constantly render the text less than itself, taking away its sense of fullness, introducing into it a subtraction. And this star's constant work of reduction-something that, as I mentioned earlier, goes against an entire tradition-calls to mind a certain "minor" tradition that anticipates Odradek, that acts (to invoke the title of Borges's essay on Kafka) as its precursor. ${ }^{27} \mathrm{I}$ am speaking of alchemy, which is often considered a theory and practice of transformation, for 
instance that of one metal into another. But this is too simplistic, as alchemy entails not so much a transformation as a purification, based on the idea that the "higher" metals exist, in a potential form, in the "lower" ones: the alchemist can seek to turn lead into gold because the latter is somehow contained in the former. Alchemy is thus based on the idea of a harmony between metals that mirrors and presupposes the harmony of the stars, since each metal corresponds to a specific planet; it thus assumes a system (a truly living system) encompassing earth and sky, one that contradicts the one I mentioned earlier, in which the stars constitute a perfection that nothing on earth could ever attain: here, stars and metals, sky and earth, are made of the same "stuff," constitute or, better, express the same material, and this unity allows the alchemist not so much to bring the heavens down to earth as to harness or participate in the power that the stars exercise in the earthly realm. The alchemist, bringing out the earth's starry nature, is the one who, like Odradek, renders the awesome mundane, without divesting it of its awe. The asterisk, in this schema, would figure as a sort of alchemical symbol, yet even this is not accurate, for where a symbol in alchemy stands over and above language, containing more power than the latter, the asterisk is that which takes language away from itself-opening it up to its own powerlessness. ${ }^{28}$

This is the place to recognize my debt to one of the greatest readers of Kafka, Maurice Blanchot, for these are the very terms through which he thinks the problem of the political: undoubtedly the register in which the "subtraction" of which I have been speaking appears most clearly in Blanchot's work is that of passivity, a passivity that can in no way simply be opposed to activity or action but is rather the essential element of a "non-power" that, for him, is essential to any politics that seeks to combat the logic of sovereignty-any politics, in other words, that seeks not only to oppose but to undo this logic. It is only this form of politics that, for Blanchot, can truly think of itself as revolutionary. The references are obviously numerous, but the most germane one here is The Writing of the Disaster, given the provenance of the latter term from the language of stars and given the extent to which Blanchot develops the logic — the writing — of this term through a sustained reflection on Kafka. ${ }^{29}$ What the disaster expresses, after all, is very close to the logic I have sought to trace 
in Kafka's story: the impoverishment whereby an entity ceaselessly becomes less than itself. ${ }^{30}$

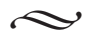

This is a good place to come back to Žižek, because, in a way, the movement of his entire book is one of subtraction. I mentioned earlier that the final section of The Parallax View is titled "The Lunar Parallax," but the complete title, in fact, is "The Lunar Parallax: Toward a Politics of Subtraction," and if this is where the book ends, it is because a certain concept of subtraction has been inherent all along to the way Žižek thinks about parallax. Throughout the book, Žižek criticizes the idea of "resistance" so popular today (protests, petitions, and so on): the problem with such actions, he argues, is that they accept the premises of their opponents and thus constitute, to go back to the terms of his Syria article, "pseudo-struggles," actually strengthening (by legitimizing) that which they purport to contest. "Subtraction," on the contrary, echoes what Žižek says about the "revolutionary gap" in his Lenin essay: it entails "the violent act of actually changing the basic coordinates of a constellation" (381). He elaborates thus:

In order for [this] kind of violence to take place, this very place should be opened up through a gesture which is thoroughly violent in its impassive refusal, through a gesture of pure withdrawal in which-to quote Mallarmé-rien n'aura eu lieu que le lieu, nothing will have taken place but the place itself. (Ibid.)

Rather than "resisting" (and remaining tied to that which is resisted), this subtraction would entail a pure opening, not so much by clearing away the prior political coordinates (this is not a strategy of simple destruction) as by holding these coordinates in suspense, in order to render a new constellation possible. The "place itself" of which he speaks is exemplary of the concept of parallax, for it is "the reduction of all qualitative differences to a purely formal minimal difference" (382), and the best example of this is the "I would prefer not to" of Melville's "Bartleby, the Scrivener": rather than negating a predicate, states Žižek, Bartleby's phrase "affirms a non-predicate" (ibid.), which allows one to envision the passage "from the politics of 'resistance' or 'protestation,' which parasitizes upon what it negates, to a politics 
which opens up a new space outside the hegemonic position and its negation" (381-82). This new space is not a clearing that one would then "fill in" with a new foundation: while the opening necessitates the "subsequent work of construction" (382) of a new community or political entity, the task of this construction is to "give body" (ibid.) to the empty space, give shape to the undetermined opening of subtraction or withdrawal.

But this emptiness in the midst of the social body, this conception of a space that necessitates a "subsequent work of construction," is the clearest indicator that Žižek, for all his talk of "pure difference" and subtraction, never truly gives up on the idea of a gap, an empty space, or (to recall Derrida's critique of Lacan) a lack; paradoxically, for a text that affirms its materialist standpoint over and over again, the problem with Žižek's framework is that it is too idealist: precisely what it does not allow is a materialism that is not somehow ordered around a gap or space. And if Žižek avoids any discussion of the stars that so obsess him, it is because, within this framework, it is impossible for him to understand the work of the star that haunts his text like no other: Odradek, the star that undertakes a work of reduction without the opening of any space or gap, the star whose flatness expresses pure subtraction. ${ }^{31}$

And, given the way this idealism haunts his text, it is unsurprising that the idealist motif par excellence, that of the pseudo-, the semblance, falsity, marks his more "journalistic" writing, writing that, far from being separate from his theoretical work, is in fact the place where the political stakes of the latter are at their clearest. This idealism leads Žižek to distinguish true politics from seemingly "ideological" conceptions, to posit struggle as pseudo-struggle, to separate revolution from everyday reality and place it on the other side of a gap. Odradek's materialism demands something very different: to inquire not into what a given struggle is lacking (the gap supposedly separating it from real struggle) but rather into the revolution that, in any given struggle, has already begun, regardless of the language spoken by the revolutionaries in question, regardless of the limits of the ways in which they conceive of their own actions-to understand revolution, in other words, not as something that is elsewhere (something more) but as something is already under way (something "less"): that is already in the process of revolutionizing itself, not by bridging 
a space or gap but by constantly enacting its own reduction. A parallax of subtraction: the unceasing impoverishment of this little star.

Cory Stockwell is assistant professor in the Program in Cultures, Civilizations, and Ideas at Bilkent University, Ankara. He is working on a book about openness in Blanchot and Bolaño and on a study of the question of style in Sessègnon.

\section{Notes}

1. In writing this, Žižek seems to go against something he himself wrote apropos of Egypt. Addressing the "liberal worry ... that there is no organized political power to take over if Mubarak goes," he writes: "Of course there is not; Mubarak took care of that by reducing all opposition to marginal ornaments, so that the result is like the title of the famous Agatha Christie novel, And Then There Were None" (2011). I should also make note of the great disappointment with which many Syrians who are normally inspired by Žižek greeted his words. The references here are numerous; for one of the best examples, see "A Response to Slavoj Žižek: Syria a Pseudo-Struggle," published anonymously on the blog Syria Freedom Forever.

2. These essays are Žižek 2002, 2007a, 2007b, and 2007c. Three of the four books for which these essays serve as introductions are published as part of Verso's "Revolutions" series.

3. All emphases within quotations in this essay are in the original.

4. Žižek is fond of repeating Mao Zedong's famous claim: "There is great disorder under heaven, and the situation is perfect." See, for instance, Žižek n.d. and 2011.

5. Quoted in Žižek 2006, 323. Žižek makes a very similar argument in his essay on Robespierre; see 2007c, xix-xx.

6. Žižek would probably not like the comparison, but to my mind, his words resonate with Laclau's approximation of the revolutionary to the mystic: if the mystic appears "detached," it is because she/he is able to see something in the present that no one else can, not something absent but rather the present's most essential element: a future already coming into being, already arrived. On this basis, Laclau compares mystical detachment to the formation of a revolutionary will. See Laclau, especially 141-43.

7. I should note that there is another book in which stars take a prominent place for Žižek, if once again in an oblique way: his recent book on Hegel, Less Than Nothing, which begins with a discussion of Galileo's "Eppur si muove." See especially pp. 3-5. One could also point here to a brief video, recorded for "Big Think.com, in which Žižek discusses von Trier's Melancholia, which deals with a planet that threatens to collide with and destroy Earth. 
8. Hamacher explains further in a footnote: "If one reads the Star-of-David hexagram as an ordering of letters, one will decipher a $\mathrm{K}$ in the left side of the triangle resting on the hexagram's basis line and traversed by two other lines. The two sides of the same triangle, together with the line of the second triangle that traverses them forms an $\mathrm{A}^{\prime \prime}$ (324 n.31).

9. It seems strange to make this claim of the Latin alphabet. Borges, in his lecture on Kabbala, notes how ridiculous it would seem to take the methods the Kabbalists used with Hebrew letters and apply them to, say, the Latin letters that make up Don Quixote (Borges 1984, 98). But, in a way, this is exactly what Hamacher is doing. Of course, Borges is a privileged author in this respect-one thinks of his short story "The Aleph," in which a point in space contains within it everything that can be seen, from every possible perspective; aleph, of course, is the first letter of the Hebrew alphabet (and directly related to alif, the first letter of the Arabic alphabet). One also thinks here of Chagall's great works to accompany the Book of Genesis, in which God's presence in the sky is figured as the letters that make up his name.

10. This is the one aspect of Odradek's appearance on which Žižek comments, writing in an endnote: "How can we not recall, apropos of the fact that Odradek is a spool-like creature, the spool in the Freudian Fort-Da game from his Beyond the Pleasure Principle" (2006, 402 n.95). The one comment Žižek makes about its appearance, in other words, serves to bring it further within a psychoanalytic framework.

11. It is a spool, for instance, but in the shape of a star rather than a cylinder; its threads and crossbar are both said to emanate from its star shape; a point of the star (along with the crossbar) allows it to stand; and so forth.

12. In her lecture "The Figure of Odradek in Kafka," Judith Butler also invokes the Magen David, saying: "I can't help wondering whether we have something like ... a Star of David with a crucifixion coming out of it."

13. See Hamacher's comments on the links between the words "name," "law" (nomos), and "nomad" on p. 313.

14. Or, to follow Erica Weitzman, "no permanent residence": Weitzman makes the compelling observation that this "is in fact no answer a child would give; it is a box to be checked off in a government questionnaire" (34)_Odradek, in other words, is speaking legalese.

15. In his essay "The Star of David: History of a Symbol," Scholem writes: The hexagram is not a Jewish symbol, much less 'the symbol of Judaism.' None of the marks of a true symbol nor its manner of origin ... apply to it. It expresses no 'idea,' awakens no primeval associations which have become entwined with the roots of our experiences, and it does not spontaneously comprise any spiritual reality. It calls to mind nothing of biblical or rabbinical Judaism; it arouses no hopes" (259). Hamacher himself makes reference to this essay, but without noting Scholem's reserve regarding this symbol.

16. What gives rise to anxiety, in other words, is this very seamlessness, the very mundaneness of this creature: as Anna Montané Forasté puts it, “Odradek no 
es tan extraño" (158). Given that it cannot die, it is even logical to think that it has always been there, preceding the housefather and his family: in a way, it is the housefather who is in his house and not the reverse. One thinks here of Deleuze and Guattari's thesis that the nomad has always existed, since the state-form "a toujours été en rapport avec un dehors, et n'est pas pensable indépendamment de ce rapport" (445).

17. To be a nomad who is not moving, as Deleuze says memorably, is to be "immobile with big strides" (Deleuze and Parnet, 37-38).

18. There is in fact one further verb the housefather uses in his description of Odradek, sich halten, which the Muirs translate as lurk: "He lurks by turns [Er hält sich abwechselnd] in the garret, the stairway, the lobbies, the entrance hall" (Kafka 1992a, 428). While this verb tells us much, it doesn't really provide a physical description of how Odradek moves.

19. For a recent discussion of the place of the asterisk in linguistics, see chapters 11 and 12 of Heller-Roazen's Echolalias. In the first chapter of his recent book Sounds, John Mowitt reflects on Heller-Roazen's discussion to think about the place of stars in Ondaatje's Coming through Slaughter, focusing both on actual stars and on the asterisks that divide the novel's sections. It is my hope that my argument concerning stars in this essay resonates somewhat with Mowitt's, particularly where he thinks, through the concept of disaster, about "the star's relation to the limit" and, more specifically, about how "the asterisk, the figure of the star, marks the limits of the text within the text" (36).

20. Parkes (1993) defines the asterisk thus: "A nota (q.v.) originally used to mark omissions in the text; subsequently used also as a signe de renvoi (q.v.) with more general application" (302). Both instances of "q.v." function as asterisks of sorts in that they send the reader away to other definitions, signe de renvoi, for instance: "Any sign used to associate matter in the text with material added in the margin, and especially a passage omitted from the text by the original copyist" (307).

21. As such, it at once obeys and disobeys-puts itself in tension with-the biblical prohibition on images, which Hamacher brings up at the end of his essay, citing Benjamin's claim about Kafka that "no writer followed "Thou shalt make no graven images" with greater exactitude'" (qtd. in Hamacher 336), but which he curiously doesn't apply to the hexagram that he earlier inscribes in his text. Odradek obeys the law in that it is nothing but text, yet at the same time twice disobeys it, given that the prohibition applies to images of that which is above us and also that which is below us: Odradek, a star rolling at our feet, is both at once.

22. One could argue that it is more silent even than other punctuation marks: while there are ways of "speaking" periods, commas, and so on (e.g., hesitation, shifts of tone), one generally "says" an asterisk in a text simply by skipping over it, perhaps making an often forgotten mental note to come back to it later.

23. I am paraphrasing the first words of The Writing of the Disaster, which run as follows: “The disaster ruins everything, all the while leaving everything intact" (1). 
24. Recall that Odradek is at once sinnlos and abgeschlossen.

25. See the subsection of The Parallax View titled "The Difficulty of Being a Kantian," 90-103.

26. Just as, for the alchemist, metal is not a "representative" of the planet it "symbolizes" but rather directly expresses the "wandering star" in question.

27. Borges's famous essay is of course called "Kafka y sus precursores."

28. Of the huge number of "alchemical" texts to which I could refer, let me cite just one, Paracelsus's famous discussion of the medical uses of alchemy in his Paragranum: "the physician must decidedly base his knowledge on the stars. He must define medicine in accordance with the stars, recognizing that the astra are both above and below" (215). While alchemy is generally held in low regard today, note that recent writers as important as Eliade and Bachelard have given it very serious treatments. For a good introduction to the subject, see René Alleau, Alchimie.

29. Indeed, he employs the term "disaster" on two occasions in his first essay on Kafka, “La lecture de Kafka," which dates from 1943 (see Blanchot 1981, 62-74). I thank one of the anonymous reviewers of this article for this insight. Where The Writing of the Disaster is concerned, see especially those numerous fragments of this text that seek to articulate a nonsovereign thinking of power-that seek, for instance, to think the disaster as "the wait for un-power [l'attente du non-pouvoir]" (11).

30. Hence, if Odradek is always just out of reach, as the family man states, this is not because it occupies a beyond but because it occupies a "before": far from growing out of its being too high, its awe consists in the fact that it is always just a little bit too low.

31. No wonder, then, that in this book that strives to develop a "politics of subtraction," Žižek constantly has recourse to a language of excess: if we focus only on his reading of Kafka, he states of Odradek that it works as "a stand-in for humanity by embodying its inhuman excess" (117); that it constitutes the "remainder of sexuation" (121); that it embodies a drive that "persists beyond ordinary death" (121); that what it stands for is the presence, to quote the title of the final section of the book's first part, of "Too Much Life!" (119). Perhaps this is unsurprising for a book whose aim is that of "expanding the concepts" (13).

\section{Works Cited}

Alleau, René. 2008. Alchimie. Paris: Allia.

Anonymous. 2013. "A Response to Slavoj Žižek: Syria a Pseudo Struggle." Syria Freedom Forever. https:/ / syriafreedomforever.wordpress.com/2013/10/18/a -response-to-slavoj-zizek-syria-a-pseudo-struggle/.

Blanchot, Maurice. 1981. De Kafka à Kafka. Paris: Gallimard. . 1995. The Writing of the Disaster. Trans. Ann Smock. Lincoln: University of Nebraska Press.

Borges, Jorge Luis. 1971. “El Aleph.” El Aleph. Madrid: Alianza.

—. 1976. "Kafka y sus precursores." Otras inquisiciones. Madrid: Alianza. 
1984. Seven Nights. Trans. Eliot Weinberger. New York: New Directions.

Butler, Judith. 2012. "The Figure of Odradek in Kafka." Lecture, European Graduate School. https: / / www.youtube.com/watch?v=v573KaWGIrc.

Deleuze, Gilles, and Félix Guattari. 1980. Mille Plateaux. Paris: Minuit.

Deleuze, Gilles, and Claire Parnet. 1987. “On the Superiority of Anglo-American Literature." In Dialogues. Trans. Hugh Tomlinson and Barbara Habberjam. New York: Columbia University Press.

Hamacher, Werner. 1996. "The Gesture in the Name." In Premises: Essays on Philosophy and Literature from Kant to Celan. Trans. Peter Fenves. Cambridge, MA: Harvard University Press.

Heidegger, Martin. 1998. "What Is Metaphysics?" Trans. David Farrell Krell. Pathmarks. Ed. William McNeill. Cambridge: Cambridge University Press.

Heller-Roazen, Daniel. 2005. Echolalias: On the Forgetting of Language. New York: Zone.

Kafka, Franz. 1991. The Blue Octavo Notebooks. Ed. Max Brod. Trans. Ernst Kaiser and Eithne Wilkins. Cambridge, MA: Exact Change.

_. 1992a. "The Cares of a Family Man." Trans. Willa and Edwin Muir. The Complete Short Stories of Franz Kafka. Ed. Nahum N. Glatzer. London: Minerva.

Kant, Immanuel. 1997. Critique of Practical Reason. Ed. and trans. Mary Gregor. Cambridge: Cambridge University Press.

Laclau, Ernesto. 2006. “On the Names of God." In Political Theologies: Public Religions in a Post-Secular World. Ed. Hent de Vries and Lawrence E. Sullivan,13747. New York: Fordham University Press.

Montané Forasté, Anna. 2011. "Una cosa extraña o la extrañeza de las cosas: Acerca de Die Sorge des Hausvaters de Franz Kafka." Revista de Filología Alemana 19: 157-68.http:/ / revistas.ucm.es/index.php/RFAL/article/view/37059/35865.

Mowitt, John. 2015. Sounds: The Ambient Humanities. Oakland: University of California Press.

Paracelsus (Theophrastus Bombastus von Hohenheim). 2008. Essential Theoretical Writings. Ed. and trans. Andrew Weeks. Leiden: Brill.

Parkes, M. B. 1993. Pause and Effect: An Introduction to the History of Punctuation in the West. Berkeley and Los Angeles: University of California Press.

Scholem, Gershom. 1971. "The Star of David: History of a Symbol." Trans. Michael A. Meyer. The Messianic Idea in Judaism and Other Essays on Jewish Spirituality. New York: Schocken.

Van Gent, Robert H. 2006. Andreas Cellarius. Harmonia Macrocosmica of 1660: The Finest Atlas of the Heavens. Trans. Jennifer Schaudies. Cologne: Taschen.

Weitzman, Erica. 2012. “Odradek's Laughter." Journal for Cultural and Religious Theory 12, no. 1: 31-36. http:/ / www.jcrt.org/archives/12.1/ weitzman.pdf.

Žižek, Slavoj. 2013. "Syria Is a Pseudo-struggle." The Guardian, September 6. https:/ / www.theguardian.com/commentisfree/2013/sep/06/syria-pseudo-struggle -egypt.

. 2012a. Less Than Nothing: Hegel and the Shadow of Dialectical Materialism. London and New York: Verso. 
_. 2012b. "The Optimism of Melancholia." YouTube. https://www.youtube .com/ watch?v=eUIjoYDKETM.

_. 2011. "Why Fear the Arab Revolutionary Spirit?" The Guardian, February 1. https: / / www.theguardian.com/ commentisfree/2011/ feb/01/egypt-tunisia -revolt.

_ 2007a. "Foreword: Trotsky's Terrorism and Communism, or, Despair and Utopia in the Turbulent Year of 1920." Terrorism and Communism. By Leon Trotsky. London and New York: Verso.

—. 2007b. "Introduction: Mao Tse-Tung, the Marxist Lord of Misrule." On Practice and Contradiction. By Mao Tse-Tung. London and New York: Verso.

. 2007c. "Introduction: Robespierre, or, the 'Divine Violence' of Terror." Virtue and Terror. By Maximilien Robespierre. Trans. John Howe. London and New York: Verso.

2006. The Parallax View. Cambridge, MA: MIT Press.

. 2002. "Introduction: Between the Two Revolutions." Revolution at the Gates. By V. I. Lenin. Ed. Slavoj Žižek. London and New York: Verso.

. n.d. "Denial: The Liberal Utopia." Lacan.com. http://www.lacan.com/ essays $/$ ?page_id=397. 